\title{
Real of Simply Assembly Line Balancing using Fact-Model
}

\author{
Haeryip Sihombing, Habibullah Akbar, Puvanasvaran Perumal, Mohd. Yuhazri Yaakob, and Jeefferie
}

A. Razak

\begin{abstract}
This study is to examine the productivity of the designated production line related to the cycle time, takt time, non-value added activities, and product quantities in which the processing time and the number of operators are having the correlation with assembly line balancing. By using a developed simulation tool, called as Fact-Model; which having facility menus such as the graph of critical path network, working time, and production table, enable users to analyze the line assembly related to idle time and bottleneck as well as to address the unbalancing causes. Fact-Model is also facilitate users to apply their owned pictures (which is taken related to process) in order to depict and map the real characteristic of production flows. Based on the simulation carried out, where the reallocation activities in Main-Board production line are undertaken through the production process and operators reassigned, it shows that productivity is optimum.
\end{abstract}

Index Terms-Line balancing, productivity, simulation, fact-model.

\section{INTRODUCTION}

Assembly line balancing or simply line balancing is the problem of assigning operations to workstations along an assembly line, where they should be optimal in some sense [1]. Considering on this, the problem complexity, uncertainty, and constraints will increases as to the number of the processes and products variables increased [2], since the assembly works among the workstation concerned to the allocating task have to evenly-aligned as much as possible without violating any precedence flow and exceeding the cycle time. Based on this reason, the assembly tasks should be, therefore, independently allocated to a specific station towards it needs and/or made up the tasks. First, this is due to in a partition of work among stations are static, unchanging, and generally imperfect [3], especially in the preliminary design stage [4]. Second, when assembly line balancing problem arises, then it has to be solved by redesign and reconfigure the assembly line. In this sense, the workflow must be distributed uniformly on the shop floor to avoid bottlenecks due to its lead to the under-utilization of resources [5].

Hence, the implementation of the assembly line balancing (as a method of sizing production capacity) should allows for better utilization of available resources [6] by reducing the complexity to a simplified model results. This is due to the

Manuscript received October 18, 2012; revised November 28, 2012.

The authors are with Faculty Manufacturing Engineering of Universiti Teknikal Malaysia Melaka (e-mail: haery@australia.edu, habibrown@ gmail.com, punesh@utem.edu.my, yuhazri@utem.edu.my, jeefferie@ utem.edu.my). method proposed of line balancing for the production problem, so far, are missed out and lack to consider the presence and interrelation of operators against the allocated task and workstation, workshift [3], [7], [8], and the time break.

\section{LINE BALANCING}

The problem of balancing an assembly line is formally defined through the number of models, their associated tasks, the time for performing each task, and their precedence relationships in which they are as a perplexing problem for all managers, particularly when labor productivity is a primary concern [9] and the distribution of activities among the workstations should be maximum through utilization of human resources and facilities [10].

Traditionally, balancing problem on assembly lines [11] is how to minimize the number of workstations along the production line (in which the goal is interpreted as minimizing the costs of manpower) and how to maximize the rate of production or minimize the cycle time towards a number of fixed workstations. Here, to conduct the balancing an assembly line, therefore, it must constructs a diagram of the tasks involved in assembling the product, their times characteristic, precedence relations as well as a desired demand and a time cycle. This is due to line balancing as a flow-oriented production system need to use of available cycle time as efficiently as possible and allocated the resources in effectively [12], [13], in which as follows:

1) To optimize the operations in production line for a given number of workstations towards the operators and machines are therefore requires the strategy on how to optimize the line balancing through reducing the cycle time [4]. Particularly, by reducing the cycle (takt) time through equalizing the loads on the workstations [15] where each of stations on the line are ideally should receive an equal amount of work in time units. Here, the resources must be properly used to achieve maximum productivity on the shop floor and properly schedule for efficient use of available resources [15].

2) To determine optimum allocation of operations at the workstations in order to minimize the cycle time of the line for a given number of workstations, or to minimize the number of the workstations for a given cycle time need through equalizing the loads on the workstations [4]. Here, the key criteria of the production process measurement related to the number of products finished per period of times and how to allocate a fixed amount of work to the stations of an assembly system in order to maximize throughput is therefore required [16]. 
3) To achieve the desired balance and to measure the effectiveness of resources (based on the capacities at different stations related to the number of workers and how to allocate the workers between the component stations and the assembly stations) are therefore need to be well-organized planned, especially towards the workstation in sequence where the specific production requirement is required. Besides, the abilities of each worker towards the jobs on designated workstations for high productivity, lower cycle time, and lower rejection rate.

Aforementioned above, the target line is typically needs to be rebalanced rather than balanced [1]. In this sense, line balancing problem is not only related to the problem of line design with nearly equal distribution of tasks among the stations or the adaptation of tasks to the speed of the workers, but also to the stability of the system and the reliability of the production set up [17]. Instead on merely adapting the theoretical solutions, the practical application to real problems should therefore need to be taken as an ultimate consideration since balancing and sequencing have different planning horizons [13] and real-world manufacturing problems contain of nonlinearities, combinatorial relationships, and uncertainties that are too complex to be modelled analytically [18].

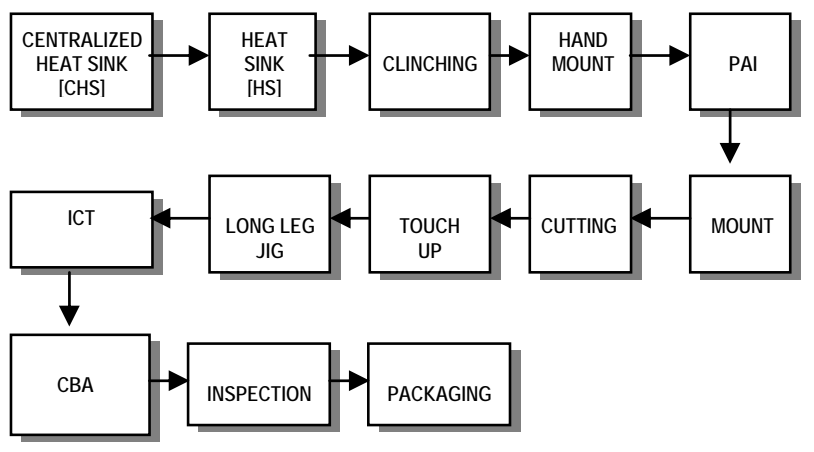

Flow chart of line production

\section{Simulation FOR PRODUCTIVITY}

This study discuss the production line to manufacture the electronic component (mainboard) with line balancing requirements. Since the productivity is related to the input and output, factors or variables influenced to the line balancing (i.e. the number of operators, equipment, and machines) will determine the working time consumed for completing one process of product manufactured based on sum of the cycle times taken at every process related. In order to diagnose the current status of the assembly line, the relevant information of line balancing (no. workstation, process sequence, time idleness, efficiency rates, and cycle time) are analyzed through the precedence diagram shown in Fig. 1 and Fig. 2, where the quantity in Table I.

Table I show that thirteen (13) operators are involved in the Main Board manufacturing process, while the total cycle time is $179 \mathrm{sec}$. To examine the balancing level, the ratio and efficiency of line balancing is calculated (Table 2). Due to the target is not achieved (since the takt time is $18 \mathrm{sec}$ for target 1500 pcs.) cause the Mount and PAI cycle time is 22 sec and 19 sec respectively, in order to make the lines production in balance and at the same time it also reducing the cycle time, the operation therefore need to reallocate the operators. However, prior to reallocate the process, the removing of the non-value added activities are needed against as follows:

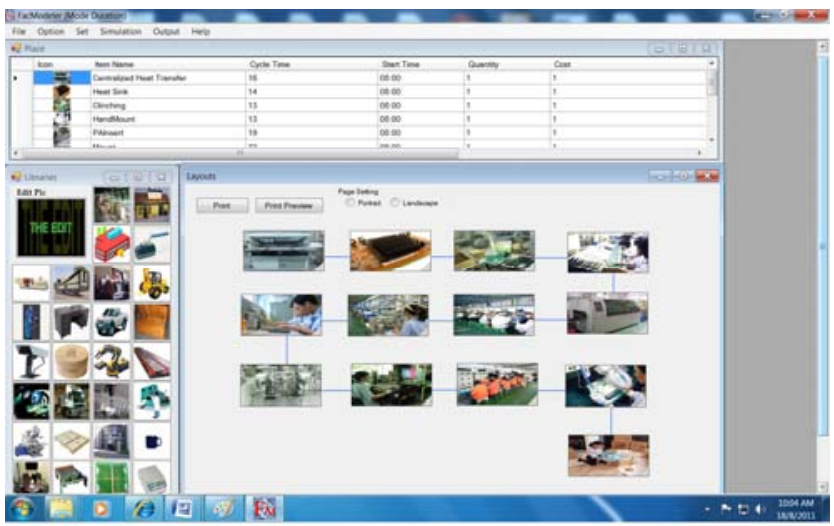

Current state of flow chart of line production using fact-model

Fig. 1. Production flow

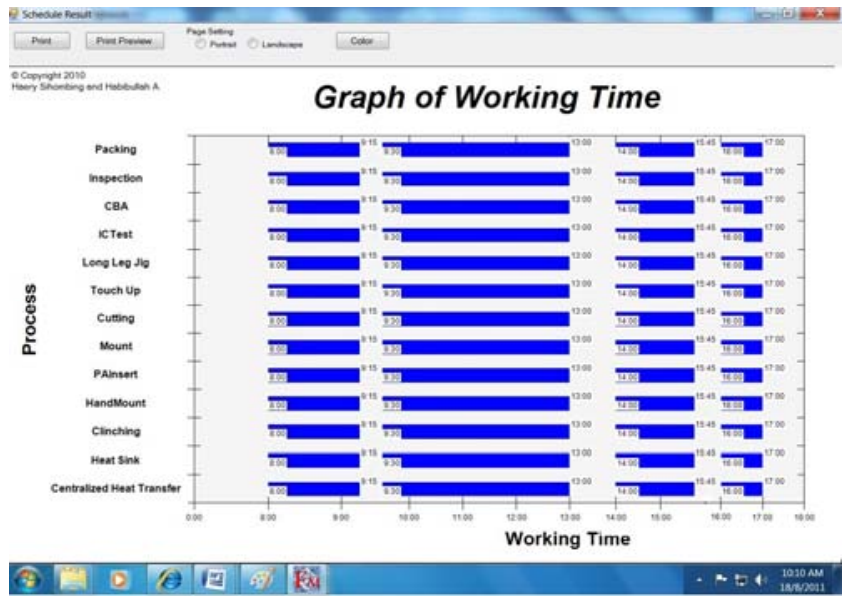

Production graph of working time $08.00 \sim 17.00$

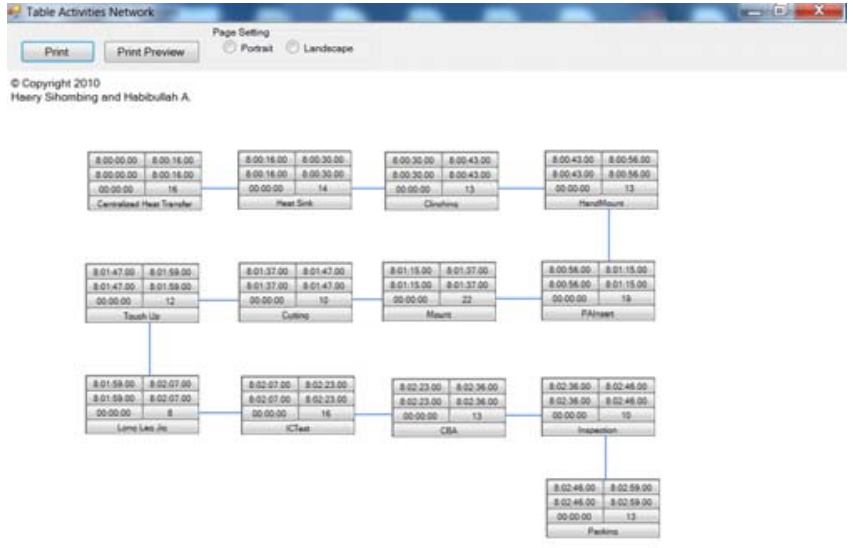

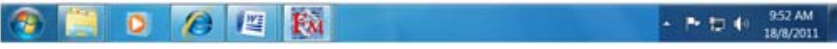

Current state of network path and cycle time

Fig. 2. Working time and network path (current state) 
TABLE I: PROCESS VS. CYCLE TIME

\begin{tabular}{|c|c|c|c|c|c|c|c|c|c|c|c|c|c|c|}
\hline \multirow{2}{*}{ Process Name } & \multirow[b]{2}{*}{ Op. } & \multirow{2}{*}{$\begin{array}{l}\text { Cycle } \\
\text { Time }\end{array}$} & \multirow{2}{*}{$\begin{array}{c}\text { 08:00 } \\
09: 15 \\
\text { QTY }\end{array}$} & \multirow{2}{*}{$\begin{array}{c}\text { 09:30 } \\
13: 00 \\
\text { QTY }\end{array}$} & \multirow{2}{*}{$\begin{array}{c}14: 00 \sim \\
15: 45 \\
\text { QTY }\end{array}$} & \multirow{2}{*}{$\begin{array}{c}16: 00 \sim \\
17: 00 \\
\text { QTY }\end{array}$} & \multicolumn{2}{|c|}{ TOTAL } & \multicolumn{2}{|c|}{ Current State } & \multicolumn{4}{|c|}{ Future State } \\
\hline & & & & & & & $\begin{array}{c}\text { W/ } \\
\text { hours }\end{array}$ & QTY & & $\begin{array}{l}\text { Idle } \\
\text { Time } \\
\end{array}$ & Op. & \begin{tabular}{|l|} 
Cycle \\
Time
\end{tabular} & & $\begin{array}{l}\text { Idle } \\
\text { Time }\end{array}$ \\
\hline Centralized Heat Transfer & 1 & 16 & 281 & 788 & 394 & 225 & 7.5 & 1688 & $88.89 \%$ & $11.11 \%$ & 1 & 25 & $138.89 \%$ & $-38.89 \%$ \\
\hline Heat Sink & 1 & 14 & 321 & 900 & 450 & 257 & 7.5 & 1928 & $77.78 \%$ & $22.22 \%$ & - & 0 & $0.00 \%$ & $0.00 \%$ \\
\hline Clinching & 1 & 13 & 346 & 969 & 485 & 277 & 7.5 & 2077 & $72.22 \%$ & $27.78 \%$ & 1 & 13 & $72.22 \%$ & $27.78 \%$ \\
\hline HandMount & 1 & 13 & 346 & 969 & 485 & 277 & 7.5 & 2077 & $72.22 \%$ & $27.78 \%$ & 1 & 13 & $72.22 \%$ & $27.78 \%$ \\
\hline PAlnsert & 1 & 19 & 237 & 663 & 332 & 189 & 7.5 & 1421 & $105.56 \%$ & $-5.56 \%$ & 1 & 19 & $105.56 \%$ & $-5.56 \%$ \\
\hline Mount & 1 & 22 & 205 & 573 & 286 & 164 & 7.5 & 1228 & $122.22 \%$ & $-22.22 \%$ & 1 & 22 & $122.22 \%$ & $-22.22 \%$ \\
\hline Cutting & 1 & 10 & 450 & 1260 & 630 & 360 & 7.5 & 2700 & $55.56 \%$ & $44.44 \%$ & 1 & 10 & $55.56 \%$ & $44.44 \%$ \\
\hline Touch Up & 1 & 12 & 375 & 1050 & 525 & 300 & 7.5 & 2250 & $66.67 \%$ & $33.33 \%$ & 1 & 12 & $66.67 \%$ & $33.33 \%$ \\
\hline Long Leg Jig & 1 & 8 & 562 & 1575 & 788 & 450 & 7.5 & 3375 & $44.44 \%$ & $55.56 \%$ & 1 & 8 & $44.44 \%$ & $55.56 \%$ \\
\hline ICTest & 1 & 16 & 281 & 788 & 394 & 225 & 7.5 & 1688 & $88.89 \%$ & $11.11 \%$ & 1 & 16 & $88.89 \%$ & $11.11 \%$ \\
\hline $\mathrm{CBA}$ & 1 & 13 & 346 & 969 & 485 & 277 & 7.5 & 2077 & $72.22 \%$ & $27.78 \%$ & 1 & 13 & $72.22 \%$ & $27.78 \%$ \\
\hline Inspection & 1 & 10 & 450 & 1260 & 630 & 360 & 7.5 & 2700 & $55.56 \%$ & $44.44 \%$ & 1 & 8 & $44.44 \%$ & $55.56 \%$ \\
\hline Packing & 1 & 13 & 346 & 969 & 485 & 277 & 7.5 & 2077 & $72.22 \%$ & $27.78 \%$ & 1 & 13 & $72.22 \%$ & $27.78 \%$ \\
\hline Total & 13 & 179 & & & & & & & Average & $23.5 \%$ & 12 & 172 & Average & $24.79 \%$ \\
\hline
\end{tabular}

TABLE II: THE EFFICIENCY AND RATIO OF CURRENT AND NEW LINE BALANCING

\begin{tabular}{|l|c|c|c|}
\hline & Current & By removing Heat Sink & New \\
\hline \hline Line Balancing Ratio & {$[179 /(13 * 22)]=\mathbf{6 2 . 5 9 \%}$} & {$[172 /(12 * 25)]=\mathbf{3 8 . 2 2} \%$} & {$[77.55 /(7 * 16)]=\mathbf{6 9 . 2 4 \%}$} \\
\hline Line Balancing Efficiency & {$[179 /(13 * 18)]=\mathbf{7 6 . 5 0 \%}$} & {$[172 /(12 * 18)]=\mathbf{6 3 . 7 0} \%$} & {$[169 /(12 * 18)]=78.24 \%$} \\
\hline
\end{tabular}
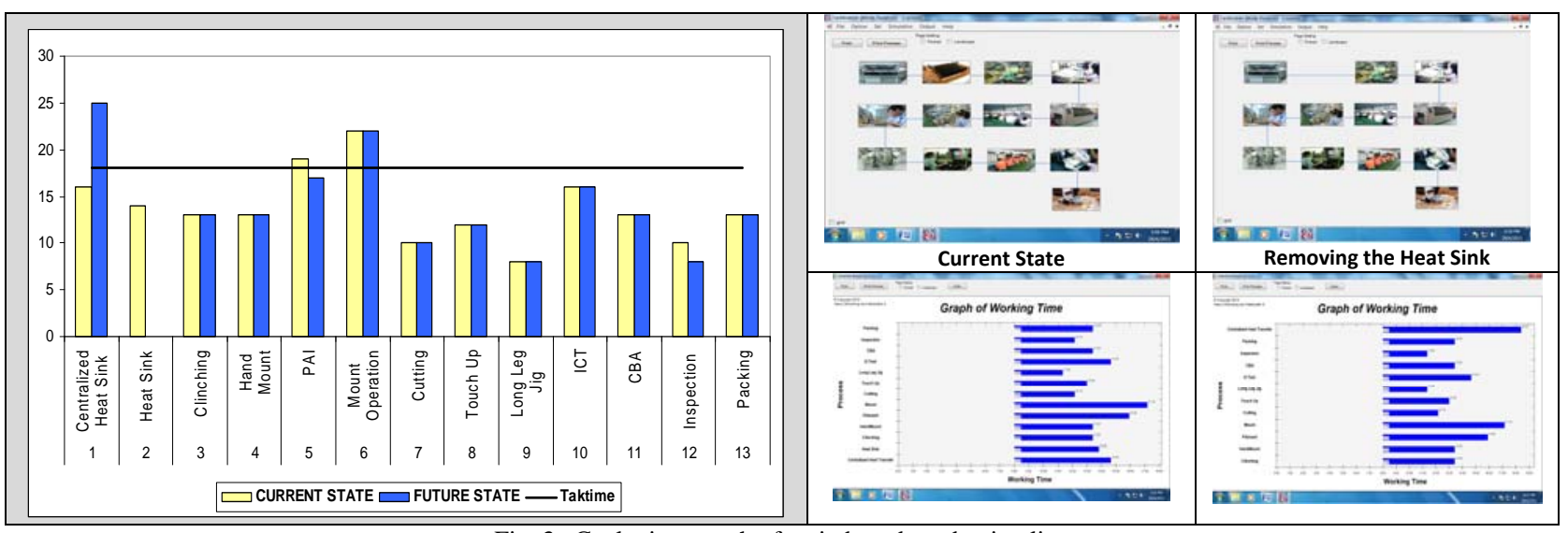

Fig. 3. Cycle time graph of main board production line

1) Heat Sink. By merging the Heat Sink to Centralized Heat Sink workstation will reduce 1 operator. However, this will affect to the increasing of the Centralized Heat Sink cycle time to $25 \mathrm{sec}$ as well as the ratio and efficiency of line balancing $(62.59 \%$ and $76.50 \%$ respectively). In table 1 shows that the efficiency and ratio of new line balancing is decreased due to the average of idle time and bottleneck is becoming higher (23.50\% to $24.79 \%$ ). Therefore, some of readjustment of new balacing strategy is required to optimize the idle time and bottleneck. Fig. 3 shows that the idle time exhibited at the certain workstations (i.e. the Clinching, Handmount, Cutting, Touch-up, etc.) due to its working time finished earlier. To address this fact, the operators who can settle their tasks earlier should, therefore, be replaced or reallocated to other workstations.

2) PAI and Mount processes, due to they have the cycle time that higher than takt time. By using why- why analysis, the improvement made is to reduce non-value added by implementing 5S, in which the cycle time of PAI reduced to $17 \mathrm{sec}$.

Moreover, due to the cycle time of Centralized Heat Sink and PAI is higher than the takt time, the reallocating the operators to others workstation are therefore required (Table
3), as follows:

1) The operator at workstation of the Clinching, Handmount, and Packing are reallocated to support Centralized Heat Sink workstation at 08.00am till $09.30 \mathrm{am}$, so as the total operator is 4 people. The total product resulted is 864 pcs, in 1.5 hours (before $1^{\text {st }}$ time break). While, the rest of the volume product (648 pcs.) is then made by 1 operator started at 09.45 to 15.15 (09.45am to $03.15 \mathrm{pm}$ ) with considering the $2^{\text {nd }}$ time break (13.00 to 14.00$)$.

2) The operator of the Clinching and Handmount workstation will start his /her activities at 09.45am (after $1^{\text {st }}$ time break). Each of them will produce the total demand of product (1500 pcs.) with the working hours finished at $16.30(04.30 \mathrm{pm})(1523 \mathrm{pcs}$.) with considering the $2^{\text {nd }}$ time break (13.00 to 14.00$)$ and $3^{\text {rd }}$ time break (15.45 to 16.00$)$.

3) An operator of the Packing workstation will start his her activities at $09.45 \mathrm{am}$. He or she will produce total demand of product (1500 pcs.) with the working hours finished at $15.45(03.45 \mathrm{pm})$ before $3^{\text {rd }}$ time break.

Furthermore, the operator at Touch-up and Long Leg Jig workstation are allocated to support Mount operation at $08.00 \mathrm{am}$ to $09.30 \mathrm{am}$, so as the total operator is 3 people. The 
total product resulted is 736pcs in 1.5 hours (before $1^{\text {st }}$ time break). While, the rest of volume product (777 pcs.) is then made by 1 operator started at $09.45 \mathrm{am}$ to $03.30 \mathrm{pm}$. Here, the operators of Touch-up and Long Leg Jig workstation will start his /her activities at 09.45am (after $1^{\text {st }}$ time break). $\mathrm{He} / \mathrm{she}$ will produce 1500 pcs. (the total demand of product) with the working hours finished at $03.45 \mathrm{pm}$ and $02.15 \mathrm{pm}$ respectively (1500pcs and 1575 pcs. respectively).

Since the inspection workstation is handled by an operator who having a crucial role to check and inspect the product (that need to be independently and avoided from the job interference from production line interest), reallocating of inspection operator to other workstation is prohibited even though the cycle time of inspection activities were the lowest one (8 sec). In addition, because of the Cutting process is finished earlier $(12.30 \mathrm{pm})$, but how to reallocate the operator of this process therefore need further arrangement, beside re-layout where it will effect to other workstation. For the temporary, the company let the process like that, until the process of Mount operation is stable and the TPM programs carried out to improve their efficiency are successful.

TABLE III: PROCESS TIME AND GRAPH OF WORKING TIME

\begin{tabular}{|c|c|c|c|c|c|c|c|c|c|c|c|c|}
\hline No & Workstation & Op. & $\begin{array}{c}\text { Cycle Time } \\
\text { (s) }\end{array}$ & $\begin{array}{c}\text { Process Time } \\
\text { [w/rest time }]\end{array}$ & Hrs & Min' & QTY & Start & End & $\begin{array}{c}\text { End } \\
\text { [ time scale] }\end{array}$ & $\begin{array}{l}\text { QTY } \\
\text { [real] }\end{array}$ & $\begin{array}{c}\text { Activities End } \\
\text { [Efficiency] }\end{array}$ \\
\hline \multirow{3}{*}{1} & \multirow{3}{*}{$\begin{array}{c}\text { Centralized } \\
\text { Heat Sink \& HeatSink }\end{array}$} & 1 & 25 & 10.42 & 10 & 25 & 1500 & $08: 00$ & $19: 55$ & $20: 00$ & 1512 & \multirow{3}{*}{ 15:15 [80.0\%] } \\
\hline & & 4 & 6.25 & 1.50 & 1 & 30 & 864 & 08:00 & 09:30 & 09:30 & 864 & \\
\hline & & 1 & 25 & 4.42 & 4 & 25 & 636 & 09:45 & $15: 10$ & $15: 15$ & 648 & \\
\hline \multirow{2}{*}{2} & \multirow{2}{*}{ Clinching } & \multirow{2}{*}{1} & \multirow{2}{*}{13} & \multirow{2}{*}{5.42} & \multirow{2}{*}{5} & \multirow{2}{*}{25} & \multirow{2}{*}{1500} & $08: 00$ & $14: 40$ & $14: 45$ & 1523 & \multirow{2}{*}{ 16:30 [93.33\%] } \\
\hline & & & & & & & & 09.45 & 16.25 & $16: 30$ & 1523 & \\
\hline \multirow{2}{*}{3} & \multirow{2}{*}{ Handmount } & \multirow{2}{*}{1} & \multirow{2}{*}{13} & \multirow{2}{*}{5.42} & \multirow{2}{*}{5} & \multirow{2}{*}{25} & \multirow{2}{*}{1500} & $08: 00$ & $14: 40$ & $14: 45$ & 1523 & \multirow{2}{*}{$16: 30$ [93.33\%] } \\
\hline & & & & & & & & 09.45 & 16.25 & $16: 30$ & 1523 & \\
\hline 4 & PAI & 1 & 17 & 7.08 & 7 & 5 & 1500 & 08:00 & $16: 35$ & $16: 45$ & 1535 & 16:45 [96.67\%] \\
\hline \multirow{3}{*}{5} & \multirow{3}{*}{ Mount Operation } & 1 & 22 & 9.17 & 9 & 10 & 1500 & $08: 00$ & $18: 40$ & $18: 45$ & 1514 & \multirow{3}{*}{ 15:30 [83.37\%] } \\
\hline & & 3 & 7.3 & 1.50 & 1 & 30 & 736 & 08:00 & 09:30 & 09:30 & 736 & \\
\hline & & 1 & 22 & 4.67 & 4 & 40 & 764 & 09.45 & $15: 25$ & $15: 30$ & 777 & \\
\hline 6 & Cutting & 1 & 10 & 4.17 & 4 & 10 & 1500 & $08: 00$ & $12: 25$ & $12: 30$ & 1530 & 12:30 [56.67\%] \\
\hline \multirow{2}{*}{7} & \multirow{2}{*}{ Touch Up } & \multirow{2}{*}{1} & \multirow{2}{*}{12} & \multirow{2}{*}{5.00} & \multirow{2}{*}{5} & \multirow{2}{*}{0} & \multirow{2}{*}{1500} & $08: 00$ & $14: 15$ & $14: 15$ & 1500 & \\
\hline & & & & & & & & 09.45 & $15: 45$ & $15: 45$ & 1500 & $15: 45[86.6 / \%]$ \\
\hline $\mathbf{8}$ & J ond I & 1 & 8 & 333 & 3 & 20 & 1500 & $08: 00$ & $11: 35$ & $11: 45$ & 1575 & $\mathbf{1 4 . 1 5}$ \\
\hline 8 & Long Leg Jig & 1 & 8 & 3.33 & 3 & 20 & 1500 & 09.45 & 14:05 & $14: 15$ & 1575 & $14: 15[66.6 \% \%]$ \\
\hline 9 & ICT & 1 & 16 & 6.67 & 6 & 40 & 1500 & $08: 00$ & $16: 10$ & $16: 15$ & 1519 & 16:15 [90.0\%] \\
\hline 10 & CBA & 1 & 13 & 5.42 & 5 & 25 & 1500 & 08:00 & $14: 40$ & $14: 45$ & 1523 & 14:45 [73.33\%] \\
\hline 11 & Inspection & 1 & 8 & 3.33 & 3 & 20 & 1500 & 08:00 & $11: 35$ & $11: 45$ & 1575 & 11:45 [46.67\%] \\
\hline 12 & Packing & 1 & 12 & 500 & 5 & 0 & 1500 & $08: 00$ & $14: 15$ & $14: 15$ & 1500 & $7 \%$ \\
\hline 12 & Packing & 1 & 12 & 5.00 & 5 & 0 & 1500 & 09.45 & $14: 45$ & $15: 45$ & 1500 & 15:45 [86.6\%\%] \\
\hline
\end{tabular}

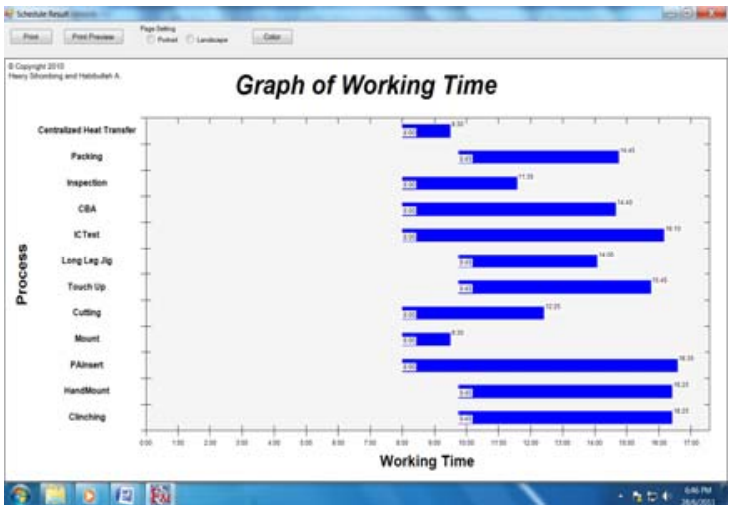

- The operator at Clinching, Hand mount, and Packing are reallocated to support Centralized Heat Sink workstation at 08.00am till 09.30am.

- The operator at Touch-up and Long Leg Jig workstation are allocated to support Mount operation at 08.00 am to 09.30am

\section{CONCLUSION}

In this study, due to the Centralized Heat Sink and Heat Sink workstation are merged into 1 workstation (in which then only 1 operator required), the total number of operators was reduced from 13 to 12 persons. However, this strategy was actually reducing the line balancing ratio from $62.59 \%$ to $38.22 \%$ and the efficiency from $76.50 \%$ to $63.70 \%$. Although by merging such workstation will increase the

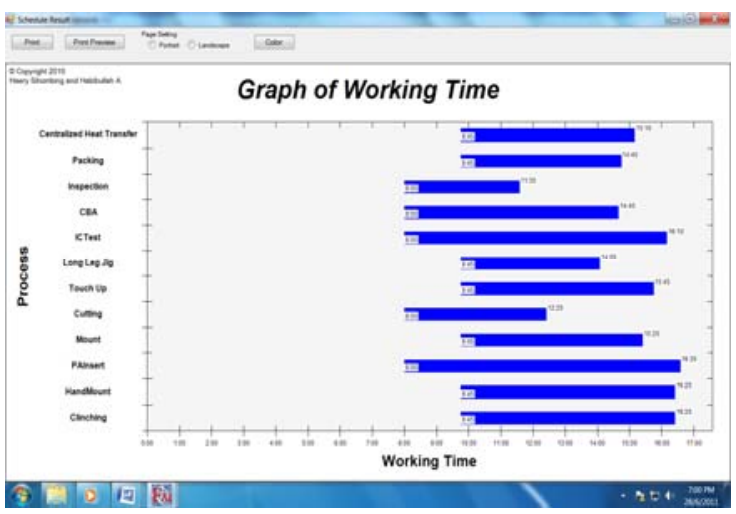

- $\quad$ The operator of Clinching and Handmount workstation will start his /her activities at 09.45am

- An operator of Packing workstation will start his /her activities at 09.45am

efficiency of operator involved, the average of bottleneck and idle time is, however, increased by $1.29 \%$. This is not as what required for line balancing purpose. Therefore, the problem of line unbalancing situation in the Main Board production line is not only requiring the reallocation of operators of Clinching, Handmount, and Packing to the Centralized Heat Sink, but also the removal of the non-value added (through implementing $5 \mathrm{~S}$ at PAI workstation). By this strategy, the 
efficiency average calculated of the working time from 12 workstations is $79.44 \%$ (Table 3 ), while the new of line balancing ratio and efficiency is increased to $69.24 \%$ and $78.24 \%$ respectively (Table 2 ). Here, the Fact-Model is used to help the simulation by mapping it through graph of the working time related to quantity and network path.

Since the increment of productivity considered in this study is in terms of the output that related to quality of product, by performing the reduction of the total worker numbers and the cycle times as well as reallocating the operator (while at the same time the outputs maintained) are, therefore, need to consider the time interchange of the jobs. This is to avoid the possibility of reject product occurred due to the confusion of operator for doing the tasks. In this study, the reallocating of operators were, therefore, undertaken to before or after the break time.

However, there are some of other improvement aspects still required to carry out productivity activities against line balancing through rebalancing the lines, especially related to the buffer stock and WIP. Besides, the further study toward the issues in the production line (that is related to quality product, layout design, and ergonomic) in order to increase the production productivities and line balancing.

\section{ACKNOWLEDGMENT}

Fact-Model is a simulation program created by Haeryip Sihombing and Habibullah Akbar. The authors would like to thank CRIM-UTeM. This project is supported by CRIM through PJP /2010/FKP (5A) S663.

\section{REFERENCES}

[1] E. Falkenauer, "Line Balancing in the Real World," in Proceedings of the International Conference on Product Lifecycle Management, 2000, pp. $360-370$.

[2] M. Gallo, G. Guizzi, and V. Zoppoli, "An Integrated Approach to Develop a Simulation Model in Manufacturing Processes," International Journal of Systems Application, Engineering and Development, vol. 1, no. 4, 2007, pp. 137-145.

[3] J. J. Bartholdi and D. D. Eisenstein, "A Production Line that Balance Itself,” Operation Research, vol. 44, no. 1, 1996, pp. 21-34.

[4] S. Masood, "Line Balancing and Simulation of an Automated Production Transfer Line,” Assembly Automation, vol. 26, no. 1, 2006, pp. 69-74.

[5] S. Rajakumar, V. P. Arunachalam, and V. Selladurai, "Simulation of Workflow Balancing in Assembly Shopfloor Operations," Journal of Manufacturing Technology Management, vol. 16, no. 3, 2005, pp. 265-281.

[6] D. Huber and W. Dangelmaier, "Controlled Simplification of Material Flow Simulation Models," in Proceedings of the 2009 Winter Simulation Conference, 2009.

[7] J. W. Herrmann, E. Lin, B. Ram, and S. Sarin, "Adaptable Simulation Models for Manufacturing," in Proceedings of the 10th International Conference on Flexible Automation and Intelligent Manufacturing, vol. 2, 2000, pp. 989-995, 2000.

[8] S. J. E. Taylor , N. Mustafee, S. J. Turner, K. Pan, and S. Strassburger, "Commercial-Off-The-Shelf Simulation Package Interoperability: Issues and Futures," in Proceedings of Winter Simulation Conference, 2009.

[9] P. M. Swamidass, "Encyclopedia of Production and Manufacturing Management,” Kulwer Academic Pubs. Norwell, Massachusetts, pp. 820.

[10] D. Roy and D. Khan, "Assembly Line Balancing to Minimize Balancing Loss and System Loss,” Journal of Industrial Engineering International, vol. 6, no. 11, 2010, pp. 1-5.

[11] A. Sprecher, "Dynamic Search Tree Decomposition for Balancing Assembly Lines by Parallel Search,” International Journal of Production Research, vol. 41, no. 7, 2003, pp. 1413-1430.
[12] N. Boysen, M. Fliedner, and A. Scholl, "Assembly Line Balancing: Which Model to Use When," in Proc. of International Journal of Production Economics, vol. 111, 2008, pp. 509-528.

[13] J. Håkansson, E. Skoog, and K. Eriksson, "A Review of Assembly Line Balancing and Sequencing Including Line Layouts," in Proceedings of PLANs forsknings-och tillämpningskonferens, Chalmers Technical University, Gothenburg, Sweden , 2008.

[14] T. Watanabe, Y. Hashimoto, I. Nishikawa, and H. Tokumaru, "Line Balancing Using A Genetic Evolution Model," Control Engineering Practice, vol. 3, no. 1, 1995, pp. 69-76.

[15] T. K. Bhattacharjee and S. Sahu, "A Critique of Some Current Assembly Line Balancing Techniques," International Journal of Operations and Production Management, vol. 7, no. 6, 1986, pp. 32-43.

[16] K. R. Baker, S. G. Powell, and D. K. Pyke, "Optimal Allocation in Assembly Systems,” Management Science, vol. 39, no. 1, 1993, pp.101-106.

[17] D. Roya and D. Khanab, "Designing of an Assembly Line based on Reliability Approach," An International Journal of Optimization and Control: Theories and Applications, vol. 1, no. 1, 2011, pp.45-52.

[18] A. Persson, H. Grimm, A. Ng, and M. Jägstam, A Case Study of Using Simulation and Soft Computing Techniques for Optimization of Manufacturing Systems, Swedish Production Symposium , 2007.

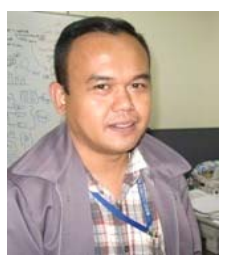

Haeryip Sihombing (@HHIP) received his degree in Electronic Engineering from ST.INTEN in 1994 and MSc. degree in Industrial Engineering from UPH (Indonesia) in 2000. He experienced working with AT\&T, Sinoca, MicroPack, and Chubb Lips. Since 2006, he has been giving a service in the Department of Manufacturing Management at UTeM as a visiting lecturer in the Faculty of Manufacturing Engineering. His research interest is in Operation Management, Product Development, Quality \& Reliability, and Strategic Management.

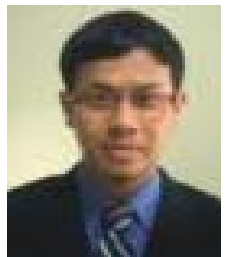

Habibullah Akbar received his B.Sc. degree in Physic ITB Indonesia 2006 and M.Sc degree in Information and Communication Technology from UTeM Malaysia in 2010. Currently, he is pursuing Ph.D. in Information and Communication Technology at UTeM. His major research and interest is in computer vision, software engineering and physics.

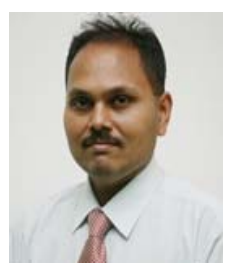

Puvanasvaran Perumal received his BSc and MSc. degree in Mechanical Engineering from UTM and UPM in 1993 and 2004. In 2009, he received PhD in Manufacturing System from UPM in 2009. Currently, he is as an academic staff in the Faculty of Manufacturing Engineering of UTeM and assigned in Manufacturing Management Department. His interest research is in Lean Management.

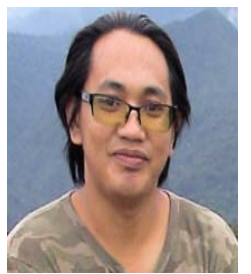

Mohd. Yuhazri Yaakob received BSc and MSc degree in Mechanical Engineering from Universiti Tun Hussein Onn in 2005 and Universiti Teknikal Malaysia Melaka (UTeM) in 2008. Currently, he is as an academic staff in the Faculty of Manufacturing Engineering of UTeM and assigned under the Engineering Materials Department. His major research interest is in Structural Composites research. He is also actively involved in the innovation and composites based product development.

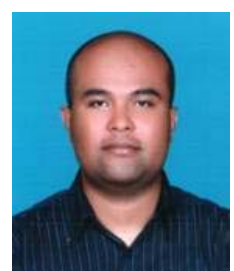

Jeefferie Abd Razak received his BSc and MSc. degree in Mechanical Engineering from USM in 2004 and UPM in 2009, Malaysia. Currently, he is as an academic staff in the Faculty of Manufacturing Engineering of UTeM and assigned under the Engineering Materials Department. His major research interest is in Polymer Engineering and Polymer Composites. 